\title{
Development System for Recognize Tajweed in Qur'an using Automatic Speech Recognition
}

\author{
Taufik Ridwan $^{1}$, Nuur Wachid Abdul Majid ${ }^{1}$ \\ \{taufikridwan@upi.edi, nuurwachid@upi.edu \} \\ Universitas Pendidikan Indonesia, Bandung, Indonesia ${ }^{1}$
}

\begin{abstract}
Tajweed is an integral part of the Qur'an, so a Moslem must learn that how to read the Qur'an in accordance with the rule of law Tajweed. Someone has a problem in learning tajweed because they have their busyness in every day, so they don't know of qaidah for the reading of the Qur'an. The research of Tajweed checking system for Qur'an actually has been implemented and developed by researcher. The researches require users to type in the text input, then the system will search and return documents that are considered relevant by the system. This research tries to do an analysis to build the prototype of tajweed law checking system in Al-Qur'an verse using transcription text from automatic speech recognition that has been built. Tajweed introduction will use a regular expression to look for certain patterns in the transcription text
\end{abstract}

Keywords: Speech transcription, regular expression, Tajweed checker, Qur'an

\section{Introduction}

In this era of technological development, society is strongly influenced by the role of technology in everyday life. Besides the busyness of someone who is getting crowded because everything is needed quickly and precisely then it is very necessary for someone to always work accurately and must utilize the time efficiently. This causes a person to prioritize a matter that is classified as more important and must be immediately implemented and ignore activities that are considered not necessarily important, as well as learning and reading the Qur'an. Reading the Qur'an becomes the most important thing for a Muslim because the Qur'an is a holy book that must be read and practiced. Although in the end, someone must be able to read it properly and correctly in accordance with the rules of law.

The Qur'an is a holy book that guides the life and the main source of law for Moslems. In reciting the Qur'an, a person is bound by a reading law called the law of tajweed. This law will be the guidance of a person in issuing the sound and set the length of the reading. However, sometimes encountered a Muslim who can read the Qur'an forgot about the law tajweed verse or piece of verse that he read. The common way that can be done is to open a legal note tajweed when he studied, or ask someone who better understands about the law of tajweed. However, the two solutions above require the media and also the person who is not uncommon difficult to find directions when someone is reading the Qur'an.

Reading the Qur'an need guidance that is expected to give the same pronunciation of everyone who read it. Tajweed is a hint that must be considered when reading the Qur'an by someone because it is not arbitrary to read it. The Tajweed becomes a guide to all who read 
and should be carried out according to their rules. Thus the function of Tajweed is very important to equate in reciting the Qur'an to all humans wherever located.

Tajweed is an art in reading the Qur'an, where everyone can't read in accordance with the accent of each region. Each person has different accents or voices, so the fear of recitation of the Qur'an has a diversity of different sounds in large numbers. Thus Tajweed became the guide to equalize the sound to match the original, namely the greeting of Arabic and Quranic recitation.

Someone is required to learn Tajweed first before reading the Qur'an, so that when read it is smooth and in accordance with the rules of the correct way of reading. But the obstacles that arise now is the need for time to learn very little, a person prefers busy outside hours to complete the work that accumulates. Someone just relies on gadgets in interacting with each other, so that in spare time is widely used to hold the gadget.

Gadgets become a huge tool for human needs, so every day will not be separated from technology tools. The idea of incorporating tajweed learning into the gadget is a very precise idea, given the high human rush. So one can study Tajweed periodically at their breaks, in the end, one can learn independently about mobile-based Quran reading the law. Although it is suggested to learn more about the Qur'an reading law to the experts, such as Ustadz or Kiyai (mention of religious leaders in Indonesia). Interactive multimedia learning can also overcome the limited experience possessed by students, generate students motivation, stimulate students to learn, and provide comprehensive experience [1].

Based on the above problems, required a system that can help to check the law of tajweed on verses or paragraph cuts in the Qur'an. The approach taken for the checking process is the word-based (lexical) approach. This approach will prompt the user to provide text input to the system, then the system will provide the responsive law tajweed asked by the user.

Users can easily learn Tajweed anytime and anywhere by using digital based applications. So the problem of busyness and lack of time to learn to the experts can be trimmed through this application. Users can download applications easily through their gadgets. In the application will be provided some features to support learning and expected users can understand it already to learn the Qur'an reading law

This research is a development of previous research [2]. The sound input on a previously built system is then used to be the input on the current system built. Therefore, the input is derived from the transcription text of the built-in speech recognition system.

Focus on this research, it will stress only build the prototype of tajweed legal checking system in Al-Qur'an verse using transcription of speech recognition system (based on text).

\section{Related Research}

The research on the Tajweed checking system of the era relates to the search system of the Qur'an. Some such research is done.

Hammo et al using the Relational Database on Modern Standard Arabic is the writing of Arabic script that does not use punctuation for the search of the verses of Al-Qur'an [3] Then Anwar et al conducted Inexact String Matching to search for Al-Qur'an verses on Arabic script which aims to allow tolerance of typographical error [4].

Istiadi searched for a phonetic resemblance to make the equivalent of Arabic script and pronunciation in the Latin script in the Qur'an. The search method used is a search with a 
trigram model that is applied to the phonetic code with the specified sameness size. It encodes the text in the verses of the Qur'an by removing spaces, and the adjustment of speech sounds. But for the use of long and short reading made it uniform. The tokenisation process uses a 3character overlapping window. For example, the trigrams of the "ARABIC" string are "ARA", "RAB", "ABI", and "BIC". In the phonetic code of the altered Quranic text, the formation of the inverted index using trigrams used as terms and verses of the Qur'an as documents. The result of the built system provides an average precision of 0.651 in the testing process. The disadvantage of this system is that based on phonetic similarity, the system can't distinguish between distinct letters [5].

Rafe searches to find out whether or not the Quranic verse of the text piece (query) in the Arabic script is entered and returns the full cut of the verse if there is a paragraph cut to the input text. The search process uses multiple pattern matching method. The database is built using words that have been omitted the reading sign [6]. Basabrain et al who tried to build a search system of Quranic verses based on topics and the number of verses containing certain snippets In his research they used several corpora such as corpus in Al-Qur'an namely corpus verse, corpus root lexicon, and corpus topic lexicon which are stored in the database [7].

Tarawneh tried to find a combination of syntax (keyword) and semantics (meaning). The text of the Qur'an is done preprocessing and encoded in an XML representation. The process of indexing and searching is done by using regular expressions in Arabic script [8]. Then, Ta'a tries to search the Quranic verse with the ontology approach he has set up in the Qur'an [9].

\section{Architecture Searching System Using Speech Transcription}

\subsection{Problem Analysis}

According to Essa and Nelson that the best recitation of the Qur'an is described as having a long character, slow rhythmic, and monotonous in speech. The Quranic recitals are known to be unique and are produced according to a set of pronunciation rules according to the tajweed rules, which are designed for clear and accurate representation. The input of this system is the signal wave and phonetic transcription of speech. One of the rules contained in the science of tajweed is the law of death or tanwin $(/ \dot{)})$ ie if the consonants in Arabic meet with dead or tanwin nun. As for more details can be seen at Table 1 .

Table 1. The law of Tajweed

\begin{tabular}{|c|c|c|c|c|c|}
\hline No & Class & Rule & letter & Example & Explanation \\
\hline 1 & Idzhar & $\begin{array}{l}\text { The sound of the } \\
\text { letters sounded } \\
\text { clearly }\end{array}$ & • $\dot{\varepsilon} \nearrow^{\prime}$ & يَنْهِهِ نَ & $\begin{array}{l}\text { Length of reading is one } \\
\text { haraka }\end{array}$ \\
\hline \multirow[t]{3}{*}{2} & $\begin{array}{l}\text { Idghom } \\
\text { Bigunnah }\end{array}$ & $\begin{array}{l}\text { melted nun sukun / } \\
\text { tanwin, with hum } \\
\text { accompanied }\end{array}$ & ي من مو & مَنْ يَقِقنُ & $\begin{array}{l}\text { Length of reading is two } \\
\text { haraka and except this } \\
\text { word is the sounded } \\
\text { clearly }\end{array}$ \\
\hline & & & & & 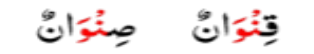 \\
\hline & & & & & 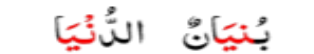 \\
\hline
\end{tabular}




\begin{tabular}{|c|c|c|c|c|c|}
\hline No & Class & Rule & letter & Example & Explanation \\
\hline 3 & $\begin{array}{l}\text { Idghom } \\
\text { Bilagunnah }\end{array}$ & $\begin{array}{l}\text { melted nun sukun / } \\
\text { tanwin, without } \\
\text { hum accompanied }\end{array}$ & ل ر & & $\begin{array}{l}\text { Length of reading is two } \\
\text { haraka }\end{array}$ \\
\hline 4 & Ikhfa & $\begin{array}{l}\text { he letters became } \\
\text { faint and the } \\
\text { buzzing }\end{array}$ & 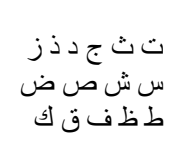 & & $\begin{array}{l}\text { Length of reading is two } \\
\text { haraka }\end{array}$ \\
\hline 5 & Iqlab & $\begin{array}{l}\text { Replace of nun } \\
\text { sukun to be a mim } \\
\text { sukun }\end{array}$ & ب & & $\begin{array}{l}\text { Length of reading is two } \\
\text { haraka }\end{array}$ \\
\hline
\end{tabular}

The sounds based on the obstruction of the discharge can be classified into the vowel sounds and consonant sounds. A vowel sound is produced by involving non-narrowing sound bands or any covering at any articulate place, whereas consonant sounds occur because the air coming out of the lungs get blocked, either in whole or in part by using articulation on one part of the speech device [10]. The smallest unit of sound is a phoneme, a sound can serve to distinguish a word with a word other.

In Arabic, some opinions mention the distribution of phonemes, first 34 phonemes. Short vowels consist of $\mathrm{a}, \mathrm{i}, \mathrm{u}$ and long vowels consisting of $\overline{\mathrm{a}}, \overline{\mathrm{i}}$, and $\overline{\mathrm{u}}$. there are 28 consonants in Arabic [11]. This amount is only for segmental phonemes, while the suprasegmental element (something that accompanies the phoneme which can be a sound pressure, short length, and vibration of sound that indicates certain emotions) is not included in this count because it can not be seen in symbolic form in Arabic. Second, 36 phonemes (two diphthongs) Arabic has 28 consonants, 3 short vowels, 3 long vowels, and 2 diphthongs namely aw and ay [12].

The letters and sounds of pronunciation in Arabic script require rules for mapping letters and sound transitions into an agreed system of writing. There are two terms in the process of creating this rule, namely transliteration and transcription. Transliteration is the transition of graphical appearance of text from one writing system into another. While transcription is an effort to transition sounds of language into an agreed system of writing.

From the phoneme contained in the Arabic language, then necessary transcription rules to map the sound transition into the agreed system of writing. One of the references in Arabic transcription writing is the International Phonetic Alphabet (IPA) standard designed by the International Phonetic Association as a Standardized Representation of the Sounds of Oral Language [12].

Table 2. Symbol of the Arabic language

\begin{tabular}{|c|c|c|c|c|c|c|c|c|}
\hline No & letter & symbol & No & letter & symbol & No & letter & symbol \\
\hline 1 & $s$ & $?$ & 13 & ش ش & $\int$ & 23 & J & 1 \\
\hline 2 & ب & b & 14 & ص & $\mathrm{s}^{\Upsilon}$ & 24 & s & $\mathrm{m}$ \\
\hline 3 & ت & $\mathrm{t}$ & 15 & ض & $\mathrm{d}_{n}^{\mathrm{S}}$ & 25 & ن ن & $\mathrm{n}$ \\
\hline 4 & ث & $\theta$ & 16 & b & $\mathrm{t}_{\mathrm{n}}^{\mathrm{S}}$ & 26 & و & $\mathrm{w}$ \\
\hline 5 & ج & ds & 17 & ظ & $\bar{\partial}^{\complement}$ & 27 & . & $\mathrm{h}$ \\
\hline 6 & $\tau$ & $\hbar$ & 18 & $\varepsilon$ & S & 28 & ي & $\mathrm{j}$ \\
\hline 7 & $\dot{\tau}$ & $\mathrm{x}$ & 19 & $\dot{\varepsilon}$ & 8 & 29 & . & $\mathrm{a}$ \\
\hline 8 & د & d & 20 & ف & $f$ & 30 & . & $\mathrm{i}$ \\
\hline 9 & ذ & $\underline{\mathrm{d}}$ & 21 & ق & $q$ & 31 & ' & $\mathrm{u}$ \\
\hline
\end{tabular}




\begin{tabular}{|c|c|c|c|c|c|c|c|c|}
\hline No & letter & symbol & No & letter & symbol & No & letter & symbol \\
\hline 10 & J & $\mathrm{r}$ & 22 & ك & $\mathrm{k}$ & 32 & 10 & Pa: \\
\hline 11 & j & $\mathrm{z}$ & & & & 33 & ي. & i: \\
\hline 12 & س & s & & & & 34 & 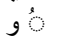 & u: \\
\hline
\end{tabular}

The transcription rules made by IPA can be analyzed that there are some symbols that are not included in the alphabetical symbol. This will make it difficult in transcribing. For that required another symbolization to make it easier. Then found the transliteration of the writing of the Qur'an with Buckwalter notation which is the development of IPA transcription. From Buckwalter notation is then performed analysis to be able to eliminate non-alphabetic symbols to find QScript modified results [13].

Table 3. Letter of the symbol in the Arabic Language

\begin{tabular}{|c|c|c|c|c|c|c|c|c|}
\hline No & letter & symbol & No & letter & Symbol & No & letter & symbol \\
\hline 1 & 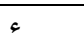 & $\mathrm{e}$ & 16 & $b$ & $\mathrm{P}$ & 29 & 'ं & $\mathrm{a}$ \\
\hline 2 & ب & $\mathrm{b}$ & 17 & ط & $\mathrm{Z}$ & 30 & . & $\mathrm{i}$ \\
\hline 3 & $ت$ & $\mathrm{t}$ & 18 & $\varepsilon$ & E & 31 & ' & $\mathrm{u}$ \\
\hline 4 & 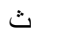 & $\mathrm{v}$ & 19 & $\dot{\varepsilon}$ & G & 32 & 10 & A \\
\hline 5 & ج & j & 20 & ف & $\mathrm{F}$ & 33 & ي. & I \\
\hline 6 & $\tau$ & $\mathrm{H}$ & 21 & ق & $\mathrm{Q}$ & 34 & 9 & $\mathrm{U}$ \\
\hline 7 & $\dot{\tau}$ & $\mathrm{x}$ & 22 & ك & $\mathrm{K}$ & 35 & 'ب & $\mathrm{Y}$ \\
\hline 8 & د & d & 23 & J & $\mathrm{L}$ & 36 & $\begin{array}{l}\text { emphatic } \\
\text { empol }\end{array}$ & $\mathrm{V}$ \\
\hline 9 & $\dot{~}$ & c & 24 & م & M & 37 & و' & W \\
\hline 10 & ر & $\mathrm{r}$ & 25 & ن & $\mathrm{N}$ & 38 & imalah & $\mathrm{F}$ \\
\hline 11 & j & $\mathrm{z}$ & 26 & g & W & 39 & emphatic & $\mathrm{O}$ \\
\hline 12 & س س & s & 27 & 。 & $\mathrm{H}$ & 40 & ikhfa & $\mathrm{N}$ \\
\hline 13 & ش & $\mathrm{X}$ & 28 & ي & $\mathrm{Y}$ & & & \\
\hline 14 & ص & $\mathrm{S}$ & & & & & & \\
\hline 15 & ض & M & & & & & & \\
\hline
\end{tabular}

QScript is a transcription text of a reading of the Qur'an translated by the modified transliteration of Buckwalter which is only symbolized by the letters of the alphabet only and without any other symbols. Here are some of the symbols used in Qscript [13].

The main problem in this research is the accuracy of speech recognition. Based on the previous research still $75 \%$. 


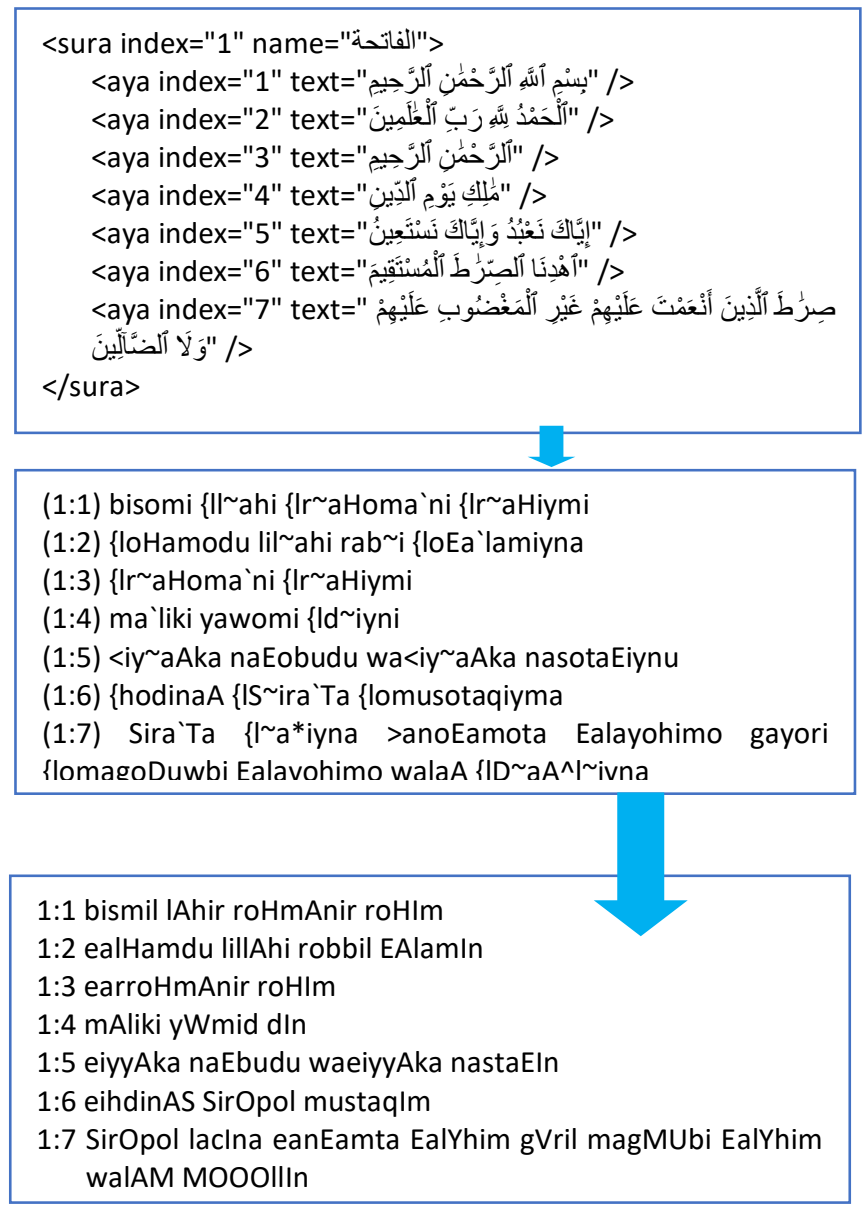

Picture 1. Process of transcription [13]

\subsection{Architecture System}

In constructing a tajweed checking system using the transcription text of the speech recognition system, we create the following architecture system as figure 2 .

From the query derived from the speech recognition system is then performed processing to produce transcription text. This transcription text will be the input on the tajweed checking system to be built. TheQuranicc text data to be indexed is a transcription cipher used in the speech recognition system training process. This is chosen because the paragraph search system used will later get a query derived from the recognition process of the speech recognition system. So it is impossible for speech recognition systems to produce voice transcription texts that are not available on the lexicon model that has been created.

The development of the Tajweed checking system begins with the process of indexing and transformation of the Tajweed Law into the Tajweed Rule (Rule) on the QScript 
transcription corpus. The rulee is what will take advantage of regular expression to recognize the pattern of tajweed law in a sentence.

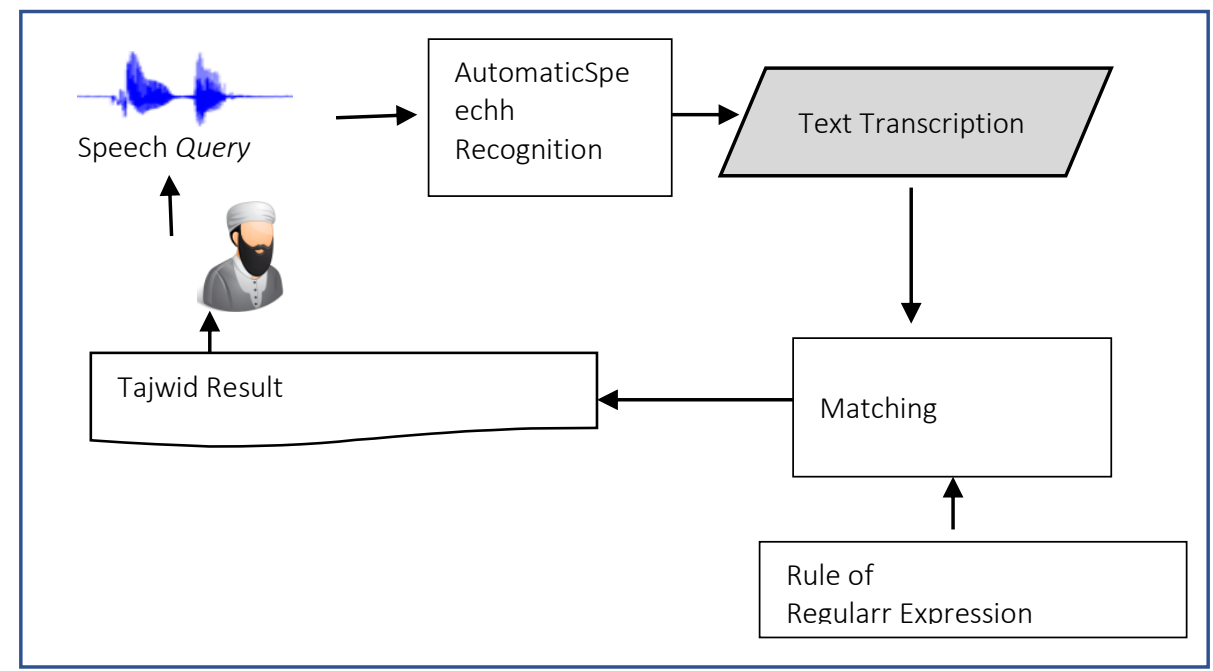

Picture 2. Architecture system

Index documents are selected word-based. Selection of words because the system will treat the needs of users into the query formulated into the word. In addition, the selection of words is also easier to analyze the search results by the checking system when there is a match or not against the rules made.

This research is carried out by some process as follow (i) Collect text transcription froma lexicon model ona training model in $\mathrm{n}$ aautomatic speech recognition, (ii) Extract the features from the text transcription to makethe rule for tajweed checker, (iii) Testing data from speech transcription testing usingregularr expression to findthe effectiveness of pattern which wasbuiltd.

\subsection{Regular Expression}

A regular expression is a string notation derived from a combination of characters with special meta-characters that when combined can look for certain patterns. One of the uses of regular expressions can be implemented to check a string with a pattern that has been created. In QScript this can then be a pattern in identifying the law of tajweed [13]. Some of them are:

1. Diftong which is the pattern for mad lin:

Other letters $+V$ or other letters $+Q$

2. Mad:

Other letters + A or other Letters $+I$ or other Letters $+U$

3. Mad Lazim Mutsaqqal Harfi or Mad Lazim Mutsaqal Kilmi:

Other letters + Mad Thobii+ Mad Thobii+ Mad Thobii

4. Mad wajib Muttashil:

$(A A$ or $O O$ or II or $U U)+e$

5. Mad Jaiz Munfashil \& Silah Thowilah: 
$0(A A$ or $O O$ or II or $U U)+$ space $+e$

6. 0 alif lam syamsiyyah:

2 letters that same in initial word

7. alif lam qomariyah:

Initial letter $+l+$ word

8. Lafal Jalallah:

Letter + LAh

For the nun sukun rule are:

9. idgham bilaghunnah :

ll or $r+r$

10. idgham bighunnah:

$m m m$ or $y$ yy or $w w w$ or $n n n$

11. Iqlab:

mmm $b$

12. Ikhfa

$N+$ letter

13. Idzhar

$n+$ letter

Then the text of this query will be a matching process with a rule that uses a regular expression that has been built. This rule comes from a one-letter encounter with other letters, or from symbolization Length or short reading. From this matching process then appears to the user about the legal information tajweed. Here are examples of some of the tajweed laws that can be identified from the Al-Fatihah letter

Teks :

Mad

Alif lam qomariah

Alif lam syamsiah
Table 3:

1:1 bismil 1Ahir roHmAnir roHIm

1:2 ealHamdu lillAhi robbil EAlamIn

1:3 earroHmAnir roHIm

1:4 mAliki yWmid dIn

1:5 eiyyAka naEbudu waeiyyAka nastaEIn

1:6 eihdinAS SirOpol mustaqIm

1:7 SirOpol lacIna eanEamta EalYhim gVril magMUbi EalYhim walAM MOOOllIn

IAhir, eiyyAka, waeiyyAka, nastaEIn, SirOpol

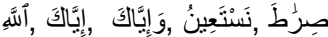

ealHamdu, EAlam In

آْلْعَمِينَ, آلْحَمْنُ

earroHmAnir

آلَرََّحْمِن 


\section{Conclusion}

Based on the above discussion, it can be concluded that the character of the Qur'an is very unique, so that in reading it requires expertise and similarity lafadz or speech. So everyone is not allowed to read the accent in each area of each. Through Tajweed one can be guided to pronounce the original sound, so that there is a similarity between one person and another, although different regions or nations. Here are the conclusions from the above discussion:

1. The result of the analysis to construct the checking system of Tajweed finds the initial conclusion that the regular expression can be used for the pattern checking process in Tajweed Law. Tajweed checking rules engine will produce and returns the matching results to the user

2. The initiall analysis concludes the error recognition rate will affect the accuracy of checking tajweed. This is understandable because the input comes from the speech recognition system. If found recognition error then automatic checking system will also make errors in checking tajweed correct.

Al-Qur'an reading checks have been developed through various technology-based applications, making it easy to learn without having to worry about running out of time or someone's busyness. The process of learning to use technology can be adjusted to the user's busyness, so there is no age limit in learning, although to be faster to master the competence is expected the user must be routine in learning.

Further research is expected to test the method of checking the pattern witha regular expression to check the law of tajweed. If there are deficiencies in the regular expression method, then a better solution can be found.

\section{References}

[1] T. Werdiningsih, M. B. Triyono, and N. W. A. Majid, "Interactive Multimedia Learning based on Mobile Learning for Computer Assembling Subject using the Principle of Multimedia Learning (Mayer)," in 3rd International Conference on Current Issues in Education, 2018.

[2] T. Ridwan and D. P. Lestari, "Spoken Query for Qur'anic Verse Information Retrieval," in Conference of The Oriental Chapter of International Committee for Coordination and Standardization of Speech Databases and Assessment Technique, 2017.

[3] J. b. Hammo, J. A. Sleit, and J. Madhajj, "Effectiveness of Query Expansion in Searching the Holy Quran," in Proceedings of the Second International Conference on Arabic Language Processing CITALA. 07, 2007.

[4] Anwar, S. Agus, Z. Abidin, and R. Kusumawati, "Mesin Pencari Ayat Al Quran Menggunakan Inexact String Matching," UIN Maliki Malang, 2010.

[5] M. A. Istiadi, "Sistem Pencarian Ayat Al-Qur'an Berbasis Kemiripan Fonetis," Institut Pertanian Bogor, 2012.

[6] V. Rafe and M. Nozari, “An Efficient Indexing Approach to Find Quranic Symbols in Large Texts," Indian J. Sci. Technol., vol. 7, no. 10, pp. 1643-1649, 2014.

[7] A. Basabrain Mohamed, A. A. A. Sharaf, and Ibraheem, "Intelligent Search Engine 
For The Holy Quran,” Int. J. Islam. Appl. Comput. Sci. Technol., vol. 2, no. 2, pp. 1629, 2012.

[8] M. Tarawneh and E. Al-Shawakfa, "A Hybrid Approach for Indexing and Searching The Holy Quran,” Jordanian J. Comput. Inf. Technol., vol. 1, no. 1, 2015.

[9] A. Ta'a, Q. A. Abed, B. M. Ali, and M. Ahmad, “Ontology-Based Approach for Knowledge Retrieval in Al-Qur'an," 2016.

[10] R. Muskar, "Diktat Kuliah Fonologi Bahasa Arab," Univ. Sumatera Utara Medan, 2009.

[11] I. Sabir and N. Alsaeed, "A Brief Description of Consonants in Modern Standard Arabic,” Linguist. Lit. Stud., vol. 2, pp. 185-189, 2014.

[12] C. Brierley, M. Sawalha, B. Heselwood, and E. Atwell, "A Verified Arabic-IPA Mapping for Arabic Transcription Technology, Informed by Quranic Recitation, Traditional Arabic Linguistics, and Modern Phonetics," 2012.

[13] R. Yuwan and D. P. Lestari, "Pengembangan Sistem Pengenalan Bacaan Al-Qur'an Memanfaatkan Phonetically Rich and Balancedd Corpus," in Konferensi Nasional Informatika ITB 2015, 2015. 